\title{
The Effectiveness of Cooperative Learning in an Online Learning Environment Through a Comparison of Group and Individual Marks
}

\author{
Marelize Malan \\ University of Johannesburg, South Africa \\ mmalan@uj.ac.za
}

\begin{abstract}
Cooperative learning is a learning approach where students are placed into groups to work towards a common goal. Prominent learning theories state that students learn best when they construct their own knowledge in an active learning environment where they can socially interact and collaborate to reach a desired outcome. Cooperative learning provides such a learning environment and has the benefit of creating an active learning community where students can develop transferable skills. Online learning has grown steadily over the past few years, but even more so during the COVID19 pandemic where tertiary institutions' only option was to continue with their academic programmes remotely through online learning platforms. With online learning becoming a prominent feature, calls are made to educators to examine teamwork and cooperation and how this can be facilitated in an online setting. In the online learning environment it is important to promote collaborative engagement to counteract feelings of isolation and encourage deep learning to occur. In the second accounting module of a fully online degree, students are exposed to a case study, with a group assignment as well as an individual assignment component. The aim of this study is to determine whether group work can be effective by comparing group marks to individual marks. The study further elicits the perceptions of the online students to determine their views regarding group work, the process that they followed to collaborate, as well as their perceptions regarding skills developed using the case study approach. A mixed-methods approach was followed, using the group and individual marks and combining those with the survey analysis and qualitative data analysis from a questionnaire. It was found that the average mark for the group assignment is higher than for the individual assignment and that the individual assignment shows a greater spread of marks. For male students who prefer to work within a group, their group mark is higher than their individual mark, showing that they did receive the benefit from working within a group. Students agreed that group work is a valuable skill that will be needed in their future careers and that the group work enabled them to learn from their group members. Working in a group requires a lot of time and effort, but students will elicit the strategies required to gain the necessary knowledge and solve the problem posed to them. Students mentioned several other skills that they perceived were developed through their exposure to the group work; skills such as communicating well, listening with intent, negotiating a point of view, researching alternatives and solving a problem were all enhanced through their participation in their groups. The results suggest that group work can be effectively achieved and managed in an online setting, albeit with special care around the logistical and technological challenges that can be experienced. Cooperative learning in the form of group work is not always welcomed by all students, but it will enable them to navigate their future careers where teamwork will be a prominent feature.
\end{abstract}

Keywords: Cooperative learning, online learning, group work, case study, skills

\section{Introduction}

The COVID-19 pandemic has resulted in schools and tertiary institutions closing their doors and continuing with the academic curriculum remotely through online learning platforms. According to a UNESCO report, by the beginning of March 2021, 144697476 pre-primary to tertiary education learners were still affected by lockdown measures, with 26 country-wide closures of institutions (UNESCO, 2021). Even before the pandemic, the global e-learning market was expected to grow at a compound annual growth rate of USD 14.6\% from 2019 to 2026 (Globenewswire, 2020). Several tertiary institutions now provide online programmes as part of their institutional offering, either in the form of short-learning programmes or complete degree programmes.

Online learning requires a unique approach to be effective and explicit forethought of the learning strategies are required for pedagogical benefits to be reached. These strategies include creating a well-designed learning environment, scaffolding the learning opportunities and ensuring that students are actively engaged so that deep learning can occur (Holzweiss, et al., 2014; Mystakidis, Berki and Valtenen, 2019). A theoretical view of engagement through the lens of online learning distinguishes between five interrelated elements that provide a tool for educators so that student engagement can be facilitated. These elements are the building of community through social engagement, activating metacognition through cognitive engagement, developing academic skills through behavioral engagement, committing to learning through emotional engagement and learning with peers formally and informally through collaborative engagement (Redmond, et al., 2018). 
A learning approach which may provide students with the opportunity to engage with their peers whilst navigating complex academic tasks posed to them, is cooperative learning. Cooperative learning has been defined as pedagogies that involve the use of groups with a robust structure to encourage interdependence and interaction and where the facilitator plays a key role in the group formation, management and structure (Ballantine and Larres, 2007; Johnson and Johnson, 2009).The terms cooperative learning and collaborative or group learning are used interchangeably at times, yet they have different features (Mclnnerney and Roberts, 2004). Collaborative learning is where social interaction occurs in student groups as a way of acquiring knowledge, but each student submits their own work. In cooperative learning, the group task is structured in such a way that group members will work as a team to achieve a common goal and are dependent on each other to complete the task (Ballantine and Larres, 2007; Johnson and Johnson, 2009). The end result might be a single group submission although each student will be individually accountable for their contribution (Mclnnerney and Roberts, 2004).

Virtual work teams emerged in organizations to share knowledge and expertise and work together on projects (Yazici, 2004). In online learning, cooperative learning can be established that will simulate in part these virtual organizational teams (Graham and Misanchuk, 2004). Research has shown that to establish cooperative learning online, it is necessary to integrate the constructivist approaches to learning with available technologies (Garrison, Anderson \& Archer, 2000; Haythornthwaite, 2006). A way to achieve this is to center the construction on solving a real-world case study, whilst ensuring that a strong community is built amongst the group members (Hernándes-Selles, Munoz-Carril and Gonzáles-Sanmamed, 2019). This will counteract feelings of isolation often experienced with online learning (Swan, Shen and Hiltz, 2006; Wolverton, Guidry Holler and Lanier, 2020). There are many benefits for including cooperative learning as a learning tool in any curriculum, but it is also included to develop graduate skills and specifically the ability to work in a team, together with the necessary communication and leadership skills (Paguio and Jackling, 2016; Yazici, 2004.).

This study focuses on the introduction of cooperative learning into a fully online accounting module with the aim to establish student engagement, simulate work teams and develop graduate skills. It further explores the effect of such a learning approach, coupled with using a real-life case study, on the performance of online students. Prior research has provided empirical evidence of the effects of cooperative learning on student performance, albeit with mixed results. Bay and Pacharn (2017) found that students on average performed better in group exams compared to individual exams, if the group exam was given a considerable weight of the final course mark. Clinton and Kohlmeyer (2005) investigated the effect of group quizzes on performance in the final exam and found no significant improvement in performance. They did however find students showing a greater motivation to learn and an increase in their ability to problem solve. Two group projects used in a statistics course had different results according to a study by Delucci (2007). The second project had a significant effect on the final exam scores, while the first project did not. Possible explanations for the differences could be the free-riding experienced in the first project that was mitigated with different group selections in project two. Using an experimental design, Opdecam and Everaert (2012) placed students randomly in team-learning tutorial groups, while other students attended lecture-based tutorials. They found that due to increased time spent by students working in teams, a higher performance on the final exam grade was achieved. Shawver (2020) also compared two groups of students - students in a cooperative learning cohort and students in traditional learning cohort - and found that quiz scores for the cooperative learning cohort was on average higher. Although studies have shown how cooperative learning interventions can affect the performance in final exams, few studies have made a comparison between group marks and individual marks using the same case study, where constructing the knowledge first is a prerequisite in solving the case study problem. The first research question is thus:

RQ1: Is cooperative learning effective when comparing the marks obtained as a group to the marks obtained as an individual within a case study format in an online learning environment?

With online learning becoming a prominent feature in tertiary education, especially in the light of the pandemic, calls are made to educators to examine teamwork and cooperation and how this can be facilitated in an online setting. This will inform the practice of educators in the years ahead, where a changed delivery model will most probably be required (Sangster, Stoner and Flood, 2020). The perceptions of online students are of particular importance here to determine their views regarding group work, the process that they followed to cooperate, as well as their perceptions regarding skills developed using the case study approach. The second research question is thus:

RQ2: How do online students experience cooperative learning or group work? 
The rest of the paper is structured as follows: In the next section, the theories on which cooperative learning is based are explored, along with the literature views on cooperative learning. The assignment used in the online module is described, as well as the mixed-methods approach employed by the study. This is followed by the results and the discussion thereof.

\section{Literature review}

\subsection{Theoretical framework}

Online learning is underpinned by theories that support student engagement, and specifically theories of active learning and social constructivism. According to Piaget's constructivist views (1971), students should construct their own knowledge; they learn best when they are active; learning should be student-centered; and social interaction and collaboration play a significant role in the learning process. This interaction with others is also seen in Vygotsky's (1978) theory of social constructivism that promotes the development of cognition in the context of social interaction. Learning based on these theories is therefore viewed as a process of active knowledge construction where cognitive and social aspects of learning are combined to solve problems together (Borthick and Jones, 2000).

Johnson and Johnson (1996) provide a further theoretical basis for cooperative learning by expanding on the cognitive development theories with theories of social interdependence. Social interdependence is characterized by individuals coming together within a group setting, sharing resources, knowledge and information, giving and receiving feedback, while experiencing greater social support and increased individual achievement. Students that prefer a deep approach to learning place a high value on such cooperative learning opportunities (Chan and Chan, 2011; Mystakidis, Berki and Valtenen, 2019).

Unique to the online learning environment are frameworks proposed by Garrison, Anderson and Archer (2000) and Redmond, et al. (2018). Consistent with constructivist approaches to learning, their frameworks propose multi-faceted elements with a strong emphasis on social connection and engagement to ensure an optimal online learning environment. In this study, cooperative learning is based on the premise that a group of individuals share in the construction of knowledge, built through the ideas and thoughts of each individual situated within an online setting (Hämäläinen and Vähäsantanen, 2011).

\subsection{Benefits and challenges of cooperative learning}

The pedagogical benefits of cooperative learning have been well-documented and substantiated in the literature. Firstly, cooperative learning provides an active learning experience for students, fitting in strongly with the reform of tertiary education to focus more on student-centered learning activities. The back-and-forth discussions that take place in groups, as well as consideration of multiple viewpoints, causes better decisionmaking in groups and more creativity (Healy, Doranand McCutcheon, 2018; Hiltz, et al., 2011). It promotes knowledge retention and an increase in motivation (Khosa and Volet, 2013). In the online environment, this could lead to an increase in the amount of participation in the online activities and quality of learning (Hiltz, et al., 2011).

Secondly, cooperative learning creates a community of learners that engages socially to form well-rounded students. Students further establish a learning network, building social capital as they learn together (Venter, 2019). As they engage socially, they confront their own beliefs and perspectives and find different ways to interpret their world (Pittaway and Moss, 2014). Thirdly, cooperative learning can foster the development of transferable skills. Interpersonal skills, including the ability to communicate well, to listen to group members and to negotiate, can all be enhanced through cooperative learning (Ballantine and Larres, 2007; Shawver, 2020). Other skills that can be improved are critical thinking and problem-solving skills (Kumi-Yeboah, Yuan and Dogbey, 2017; Opdecam and Everaert, 2012; Samkin and Keevy, 2019). What is further beneficial to the students exposed to cooperative learning is that the skills gained from cooperative learning are found to be highly transferable to work environments, where working within a team is an integral part of the business world (Kumi-Yeboah, Yuan and Dogbey, 2017; Oosthuizen, et al., 2020).

Cooperative learning at tertiary level can, however, be "demanding for lecturers and challenging for students" (Healy, Doran and McCutcheon, 2018, p.287). For educators not skilled in using cooperative learning, it might be time-consuming to set up as decisions have to be made about group size, group formation and how the group work will be assessed (Ballantine and Larres, 2007; Healy, Doran and McCutcheon, 2018). In the literature, 
debates on the ultimate group size and whether groups should be formed by the educator or by the students themselves have not provided definitive answers. Gillies (2014) found that groups of 3-4 students were most effective, whilst Christensen, et al. (2019) considered 5 students per group to be an effective group size. Groups can be formed by the students selecting their own group members or by the instructor assigning students to groups. Educators can assign students to groups by either forming homogeneous groups, heterogeneous groups or randomly select groups where group size is the only criteria (Hilton and Phillips, 2010; van der Laan Smith and Spindle, 2007). Although self-selected groups might outperform instructor-assigned groups as found by Hilton and Phillips (2010) or even increase the effectiveness of individual learning as seen by the study of van der Laan Smith and Spindle (2007), the goal of the cooperative learning task should guide the decision. If that goal is to prepare students working with a diverse mix of people one day, then randomly selected groups will better achieve the goal according to Ballantine and Larres (2007).

Students do not always find working in a group enjoyable, having to deal with lazy or uncooperative team members (free riders) and team members missing deadlines (Malan and van Dyk, 2020; Opdecam and Everaert, 2018; Shawver, 2020). To counteract these challenges, the educator should include elements in the task that will promote positive interdependence and individual accountability (Ballantine and Larres, 2007; Johnson and Johnson, 1996). When the task requires each student to contribute and they need to work together to complete the task successfully, then positive interdependence will be achieved. Similarly, individual accountability is achieved when group members are held accountable for their part in the task by the educator either conducting individual tests or a requiring a declaration from each member to confirm their contribution (Ballantine and Larres, 2007). Peer assessment can also be implemented to encourage individual accountability, but does not always solve the problem as students either refuse to complete the peer scores or prefer not to rate their peers harshly (Ballantine and Larres, 2007; Opdecam and Everaert, 2018).

Online cooperative learning can be just as effective as face-to-face collaboration, albeit with accommodation for logistical challenges. "Time, distance, technology and connectivity inadequacies" might impede the group work to be conducted, if not addressed (Robinson, Kilgore and Warren, 2017, p. 39). Educators will be required to provide additional instructions and guidance to students, specifically on how to use synchronous and asynchronous communication methods to beat the logistical challenges. The engagement of online students in cooperative learning tasks is strongly influenced by the support that they receive from the educator and it might be necessary for the educator to step in when conflict arises (Swan, Shen and Hiltz, 2006). Even though cooperative learning in the online environment has the potential to be challenging, it can be a positive experience for students, where deep learning can occur, especially when real-world case studies are used (Healy, Doran, and McCutcheon, 2018).

\subsection{Case study approach}

A case study approach to learning or case-based learning is known in a range of disciplines as a strategy to provide an active and cooperative learning space (Nkhoma, et al., 2017). When the case given is either a reallife example or based on one, then a connection with the real world is established and will require students to engage in decision-making and problem-solving (Dyball, et al., 2007; Samkin and Keevy, 2019). Case-based learning will require a shift in the way that students normally receive and process disciplinary knowledge. They will have to critically assess the case, seek the necessary knowledge and, within a group case study, discuss and listen to the ideas of their group members before being able to solve the case study problem (Borthick and Jones, 2000; Tan, 2019). When students work independently on a case, then analytical skills can be improved, while in a group setting, critical thinking skills through participation in discussions can be enhanced (Tan, 2019). It can be concluded that case-based learning is an effective teaching method that enhances learning motivation and where this is combined with cooperative learning, a range of skills can be developed (Raza, Qazi and Umer, 2020).

\section{Description of the assignment}

\subsection{Aim of the assignment}

The accounting module which is the focus of this study is part of a fully online Bachelor of Commerce accounting degree. It consists of 24 modules with each module completed over a seven-week period. The modules include several activities, designed in such a way within the Learning Management System (LMS) that students engage with the material, their peers and their educators. In the second accounting module of this degree, students are exposed to a case study, with a group as well as an individual assignment component. The case study is based 
on an actual company in the retail sector of South Africa. In the case study the company is exploring the possibility of manufacturing their own range of products, increasing loans sought and lease contracts negotiated to set up the manufacturing business. The case study is divided into four sections that pertain to these loans and leases (liabilities). Each section requires the students to first gain the knowledge of the specific liability from their textbook or other resources, before answering the questions posed. The aim of the assignment is two-fold: firstly to provide students with practice to construct knowledge first, on their own and within a group, giving them the ability to practise this in different settings. This will be valuable to students, improving their adeptness to seek knowledge first before coming up with solutions (Dyball, et al., 2007). Secondly, to expose students to a cooperative learning environment where they can develop their team work skills in an online environment.

\subsection{Group formation}

There were 66 students enrolled in the module and it was decided to use the random selection of groups available within the LMS, rather than having self-selected groups. Self-selected groups can outperform randomly selected groups (Clinton and Kohlmeyer, 2005), but can only be used effectively where the students have had prior social or academic interactions with one another (Hilton and Phillips, 2010). The students enrolled in this module are still new to the degree and might not have had any prior interactions. In this online degree, students can also take different modules at different times, exposing them to new classmates with every new module. The simple random allocation of students to groups with regard only to final group size provides for deliberately unbalanced groups (Healy, Doran, and McCutcheon, 2018). There were 14 groups in total created (with four to five members in each) and each group was given one section of the case study to solve.

\subsection{Group management}

To prepare the students for group work and to encourage them to get acquainted as quickly as possible, the groups were created within the second week of the module. This provided the students with ample time to meet and discuss the case study before the due date at the end of the fifth week of the module. Extensive guidance was given to the students on how to communicate within a virtual environment, whether or not to choose a leader for the group, and how to resolve conflict within the group. The final group deliverable could be in any format (video, written document or narrated slides) and examples were provided as well as links to software that could be used. This was all done to provide clarity and guidance at the start of the group process which could result in better performance and an overall improved group experience (Opdecam and Everaert, 2018).

To further maximize cooperation in groups, elements of cooperative learning was specifically included (Johnson and Johnson, 2009). The mark for the group work amounted to a substantial weight of the final course mark to provide for interdependence and an incentive to the group work (Bay and Pacharn, 2017). To achieve individual accountability, students were required to provide confirmation of their contribution within the final group submission and to respond to the question regarding group dynamics posed to them. Due to the problems associated with peer assessment, it was decided not to incorporate it in the grading process (Opdecam and Everaert, 2018).

\subsection{Assessment of the assignment}

To ensure the reliability of the scores, the group assignment and the individual assignment were marked based on a rubric with clearly defined parameters that were communicated to the students at the start of the assignment (Gikandi, Morrow and Davis, 2011). For the individual component of the assignment, students could choose any of the other case study sections to solve individually. They were not allowed to collaborate on this section with their group members and had to work through the problem on their own.

\section{Methodology}

A mixed-methods methodology was considered appropriate (Tashakkori and Creswell, 2007), combining group and individual marks, survey analysis and qualitative data analysis into the interpretation phase. This was done to determine the extent to which the findings from one data collection method complemented the findings of the other. Marks for the assignments were retrieved from the LMS and analysed. Survey data were collected through a self-administered questionnaire using a purposive sampling technique (Palys in Given, 2008). Both closed-and open-ended questions were included in the questionnaire. Closed-end questions were asked to limit students' responses for more consistency and better comparability of responses and were based on the questions of Healy, Doran and McCutcheon, (2018). The open-ended questions were included in the 
questionnaire for deeper insight into the students' perceptions of the group management process and the possible skills developed by their exposure to the assignments.

A link to the web-based questionnaire was emailed to all students enrolled in the module. Before distribution, students were informed of the study and purpose thereof and that the results will only be used for research purposes. The questionnaire consisted of three sections: Section 1 contained questions of a biographical nature that were used to create a profile of the participants; Section 2 contained the closed-ended questions, measured on a five-point Likert scale, ranging from 1 (strongly disagree) to 5 (strongly agree); Section 3 contained the open-ended questions requesting the students' comments and perspectives.

An independent statistician analysed the quantitative data using Statistical Package for Social Sciences (SPSS). Data from the open-ended questions were analysed through a process of thematic content analysis (Henning, van Rensburg and Smit, 2004).

\section{Findings and discussion}

\subsection{Respondent profile}

A total of $54(82 \%)$ responses were received from the student population. Of this sample, 29 (53.7\%) were female and $25(46.3 \%)$ were male. The majority of the respondents, 29 (53.7\%), indicated that English is their home language, while 13 (24.1\%) speak Afrikaans and 12 (22.2\%) an indigenous South African or African language at home. The age of the respondents ranged between 19 and 86 years, with most of the respondents (32) being older than 25 years. This finding is similar to those from other studies that also found online students to be older and with various social roles in life providing them with the opportunity to work, study and have a family at the same time (Jopp and Cohen, 2020).

\subsection{Group and individual mark}

To determine the effectiveness of cooperative learning by comparing the marks obtained from a group assignment to those of an individual assignment, the following results as shown in Table 1 were noted.

Table 1: Group and individual mark (as a percentage)

\begin{tabular}{|l|c|c|c|c|}
\hline & N & Mean & Minimum & Maximum \\
\hline Group assignment mark & 54 & 77.81 & 70 & 88 \\
\hline Individual assignment mark & 50 & 72.24 & 44 & 96 \\
\hline
\end{tabular}

All students had a group mark, but four students did not complete the individual assignment. On further investigation, three of the four students indicated that they were unable to complete the individual assignment due to work commitments, while the other student decided to terminate his studies at the time. From Table 1 it can be seen that the average mark for the group assignment is higher than for the individual assignment, but that a higher mark was achieved by a student for the individual assignment. A greater spread of marks is noticed for the individual assignment, with two students receiving less than $50 \%$ for their individual assignments. A Spearman's Rank Order Correlation test showed no statistical correlation $(p<0.05)$ between the group mark and the individual mark ( $t(54)=0.037, p=0.801)$, indicating that a high group mark did not necessarily result in a high individual mark. This could show that some students benefited from the group's problem-solving abilities and better performance but were unable to copy that approach fully to their individual assignments.

Students were asked to indicate their preference for working on their own or within a group and 44 (82\%) indicated that they preferred to work on their own. As online learning is often chosen by students for the flexibility it affords them and autonomy in how and when they engage, this result is not unexpected (Barnard, et al., 2009). Four females and six male students indicated that they prefer to work within a group, contradicting the findings of Opdecam, et al. (2014), where female students were found to prefer team learning. When the group and individual marks were compared to the students' preference to work on their own or within a group, it was noted that for female students the marks were mostly within range of each other (between $70 \%$ and $80 \%$ ), apart from three outliers, as shown in Figure 1. 


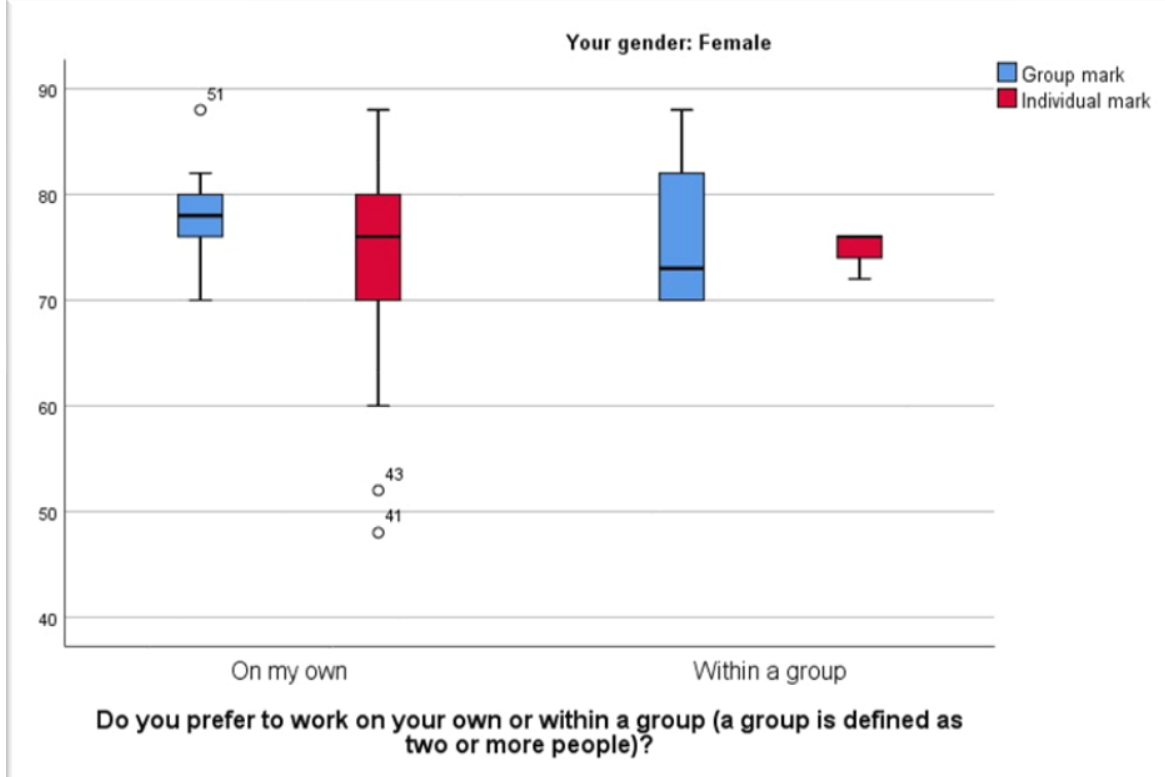

Figure 1: Preferences compared to marks for female students

For male students, Figure 2 shows that the group mark was higher than their individual mark for those that prefer to work within a group and that they received the benefit from working within a group. The possibility of free riding, where advantage is taken of the group members' knowledge and effort and subsequent higher marks, could be a reason for the lower individual mark obtained (Shawver, 2020).

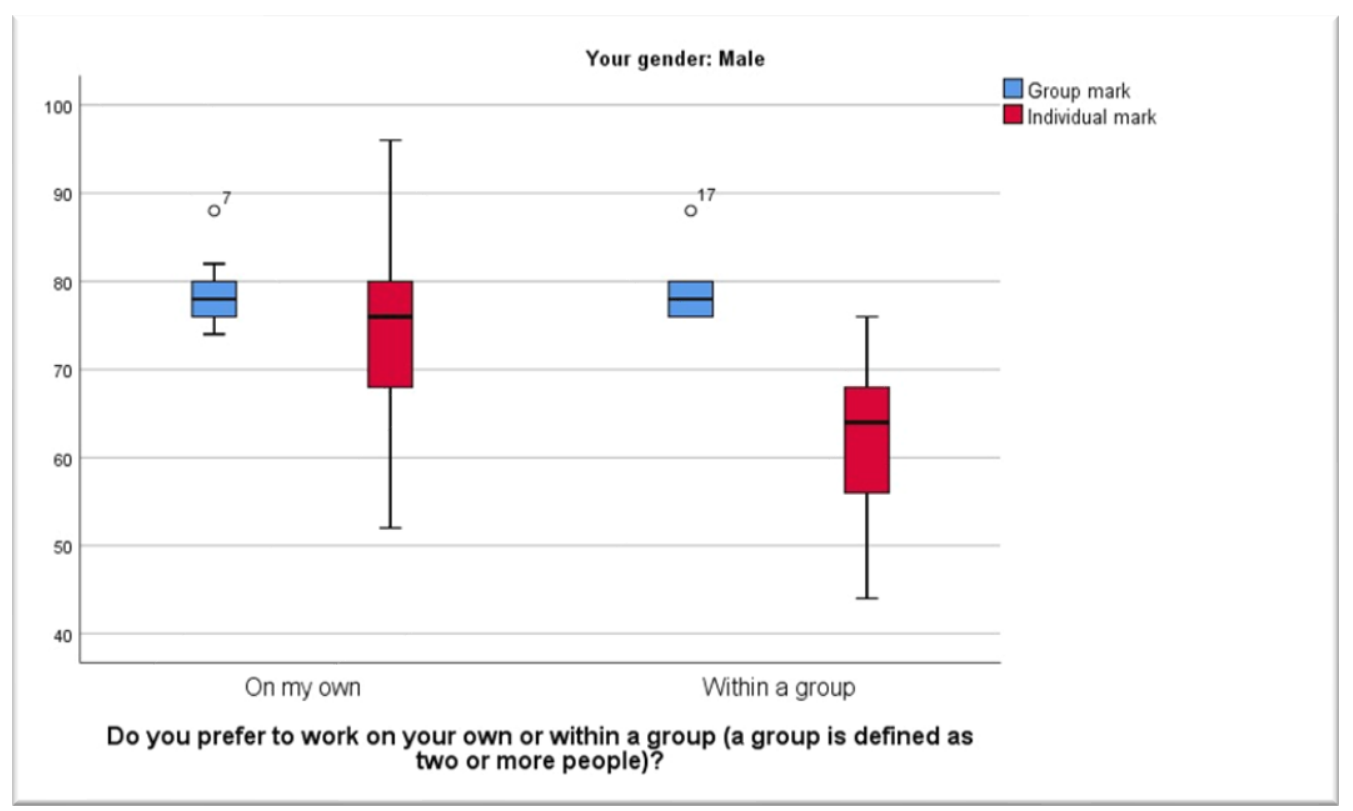

Figure 2: Preferences compared to marks for male students

Although differences can be observed from Figure 1 and Figure 2, for both males and females that prefer to work on their own, their individual marks are within range of their group marks. This may indicate that these students will make an effort and apply themselves, whether they are working on their own or within a group.

\subsection{Findings from the survey's closed questions}

Respondents were asked eight questions about the value and assessment of group work to determine their perceptions on how it enabled learning. The results are shown in Table 2. 
Table 2: Students' perceptions on the value and assessment of group work

\begin{tabular}{|c|c|c|c|c|c|c|}
\hline Question number and item & $\mathbf{N}$ & $1-2$ & 3 & 4-5 & Mean & SD \\
\hline 7. Group work enabled me to learn from other & 54 & 4 & 7 & 43 & 4.17 & 0.986 \\
\hline 8. Group work helped me to learn more about the & 54 & 8 & 11 & 35 & 3.81 & 1.150 \\
\hline $\begin{array}{l}\text { 9. I learn more about the subject area from individual assignments } \\
\text { than from group work }\end{array}$ & 54 & 9 & 17 & 28 & 3.67 & 1.099 \\
\hline $\begin{array}{l}\text { 10. The group assignments taught me how to work } \\
\text { effectively in a team }\end{array}$ & 54 & 4 & 9 & 41 & 4.04 & 1.027 \\
\hline $\begin{array}{l}\text { 11. Group work provides a skill which is valued by } \\
\text { employers }\end{array}$ & 54 & 3 & 1 & 50 & 4.35 & 0.850 \\
\hline $\begin{array}{l}\text { 12. I produce better work by working alone than by } \\
\text { groups }\end{array}$ & 54 & 7 & 19 & 28 & 3.57 & 1.002 \\
\hline $\begin{array}{l}\text { 13. Group work required more effort than } \quad \text { individual assignments } \\
\text { for the marks involved }\end{array}$ & 54 & 9 & 6 & 39 & 3.85 & 1.188 \\
\hline $\begin{array}{l}\text { 14. Some individuals get higher marks than they } \\
\text { group work }\end{array}$ & 54 & 15 & 14 & 25 & 3.28 & 1.235 \\
\hline
\end{tabular}

Scale: 1 = Strongly disagree; 2 = Disagree; 3 = Neither disagree nor agree; 4 = Agree; 5 = Strongly agree

From Table 2 it can be seen that students understand the importance of group work as they view it as a skill valued by employers, with $93 \%$ agreeing or strongly agreeing with the statement (Question 11). Their responses further show that they did learn from other students through their exposure to group work, with $80 \%$ agreeing or strongly agreeing with the statement (Question 7). The mean result for this statement (4.17) is slightly higher than the mean result reported (3.96) in the study by Healy, Doran, and McCutcheon (2018) for the same question asked of undergraduate students in Ireland. From the results it also appears as though students learned more from the subject area within a group (Question 8) than what they reported on within their individual capacity (Question 9). As the case study required students to seek the necessary knowledge first to solve the case study problem, working within the group may have contributed to the higher perception that more knowledge was gained in the group setting than individually.

What is further noticeable from the results of question 12 is that only 28 (52\%) students agreed or strongly agreed that they produce better work by working on their own. With $44(82 \%)$ of the students indicating at the start of the questionnaire that they prefer to work on their own, this result is surprising. It appears that in this group assignment, with the critical analysis of the case study that was required as well as the knowledge that had to be gained, students were skeptical of their individual ability to solve the case study problems. They might have gained from the group problem-solving and decision-making abilities that are enhanced within a real-life case study (Dyball, et al., 2007). It further appears that in this study students did not feel cheated with the group marks received, with more students disagreeing or being neutral (54\%) on the question of whether some individuals get higher marks than they deserve in group settings (Question 14). This is in contrast with the findings of Healy, Doran, and McCutcheon (2018), where more students appeared to have been unhappy with their group mark and the possibility of free riders within their groups (mean of 4.39 reported).

\subsection{Qualitative findings}

\subsubsection{Group management process}

On the question of group formation, it was interesting to note that most students (42) preferred to have been placed in a group rather than selecting their own group members. This might be a product of the diversity of students within the module and that they have not yet formed strong social bonds. The easy method of group formation through the LMS confirms the notion set forth by van der Laan Smith and Spindle (2007, p. 164) that "group formation need not involve a complicated and time-consuming mechanism".

One respondent, however, commented on the mismatch in experience and age of the different group members and how group members unskilled in teamwork could not cooperate effectively (Johnson and Johnson, 2009): 
I feel in this program you have young students who has not group experience and other guys with plenty, which I think does not work well. It should be a positive but because of time constraint other guys take over and the younger guys just follow which is not the best in my view (Respondent 53).

Students used a combination of platforms to meet as a group, with most groups indicating that they communicated with each other regularly on social media platforms such as WhatsApp. They also made use of video platforms such as Zoom, Blackboard Collaborate and Jitsi, where they could share their work and interact more formally. From their response to the question of how often they met, it was confirmed that group work requires significant time, with one student indicating: "We had 7 sessions ranging from \pm 30 min to 2 hours" (Respondent 21). Even though there is the perception that group work reduces the workload on students, other studies have also indicated that the coordination of the group, the discussion of the problem and possible solutions, as well as bringing it all together in a final deliverable, necessitates additional time to complete group assignments (Healy, Doran, and McCutcheon, 2018; Opdecam and Everaert, 2018).

\subsubsection{Group process to solve the case study problem}

Respondents were asked to describe the process that they followed as a group to gain the necessary knowledge of the specific liability that they identified and to solve the questions posed by the case study. Similarly to the findings of Hilton and Phillips (2010), the qualitative analyses of the question revealed two strategies followed by the groups to solve the case study problem: together-divide-then-regroup; or divide-then-regroup. The "allfor-one" strategy identified by Hilton and Phillips (2010, p. 27) was slightly adjusted by the students in this study to still include a component of individual work after their initial discussions and brainstorming. This might have inadvertently saved them some time as a disadvantage of the all-for-one strategy is the immense amount of time it takes when all aspects of a case study are completed together (Hilton and Phillips, 2010).

Those groups that followed the together-divide-then-regroup strategy met as a group at the start to identify the specific liability, then researched the liability individually, meeting again to discuss their findings and come up with an appropriate solution. They would then divide the work into different sections to be completed by each individual member and then bring it all together into the final deliverable. This is how two respondents described their group process:

We identified the applicable material in the text book as well as 1 or 2 external sources and then instructed everyone to go through it in order to get a better understanding of the liabilities. On the second meeting a solution was tabled as a starting point for the discussion and everyone's opinion heard. We finally reached consensus on our approach/identification and then gave each member a certain part of the accounting process to prepare and present (Respondent 21).

We read through the brief and try to establish a good understanding of what is required, then we compiled a outline of deliverables. We then allowed each member to research and read through the textbook, find examples, extra information regarding the topic. Relating back to the deliverables of the assignment, we each volunteered a task to produce information for the PowerPoint, we then had 2 zoom sessions where we put the PowerPoint together and worked through the assignment on what journal entries must go where, the calculations to be done etc. Each member giving their input of understanding and challenging each other to clarify and gain understanding (Respondent 28).

It appears from groups using this approach that more cooperative learning occurred and that they could benefit from the discussion that unfolded in the groups. It further appears that these groups unconsciously used a deep approach to learning, as confirmed by this comment:

It was a co-operative process where we all attempted a task and shared it with each other and received feedback in order to make corrections and learn (Respondent 37).

The divide-then-regroup strategy seemed to be no less rigorous, although more individuality was necessary to complete the case study:

We gathered our subject matter according to the task given. We broke up the work amongst the 5 of us, by giving each person a topic, i.e. identification, recognition, measurement, presentation and disclosure. Afterwards we would discuss how we [were] going to fit everything together and whether or not there are people with different views that need to be considered (Respondent 39). 
We first planned on how the whole assignment will be constructed and allocated parts that each group member will do. All completed files were posted on the group file exchange bar on Blackboard. Each member had a chance to review the work and make any changes/corrections/additions (Respondent 43).

Although not specifically asked, a few groups did mention making use of a group leader and one respondent indicated how frustrating it is when leadership skills were not applied appropriately:

The process was quite difficult as there was a lack of communication and the group leader not fulfilling

her role (Respondent 31).

Most respondents indicated that they followed the same process with the individual assignment - they identified the liability from the case study first, then they researched that liability before answering the question posed. A few respondents mentioned that when it came to completing the individual assignment, they missed having the decision-making abilities and generating options found within the group setting (Hiltz, et al., 2011):

But as an individual you cannot ask anyone if you are experiencing difficulties (Respondent 3).

I actually enjoyed comparing my answers with someone in the group (Respondent 8).

\subsubsection{Skills developed}

Students were asked two open-ended questions regarding skills development. The first question asked them whether working collaboratively is a skill that they will need in their current or future careers, while the second question explored whether other skills were developed by completing the assignments. On the first question only four respondents answered negatively, with one respondent explaining it as follows:

I work better by myself as others bring me down with either their pace or laziness. I delegate work when I don't have the capacity to complete it by myself in a certain time frame. I work well with others but don't feel that it is a skill that will benefit my career (Respondent 36).

In the online environment, it might be more challenging to gauge every group member's commitment as a lot of interaction happens 'offline' and uncommitted members can hide more easily:

Unfortunately, the online environment/setup in which we are currently doing these group tasks can be very frustrating as one cannot control everyone's commitment and dedication to the process and places unnecessary pressure on individual member of a team through no fault of their own (Respondent 21).

Quite a few students were able to make the connection between this group assignment and work teams that they have either already encountered or envisage that they will encounter in their future careers:

Few meaningful deliverables have a scope or size that requires the effort of only an individual. Most projects require a team to successfully deliver the agreed outcomes (Respondent 1).

I will be honest that I am not a fan of collaborating with others - I prefer to work be on my own, in my own space and work. But that's not how life works. Almost always in companies you are required to work as a team, especially in bigger corporations (Respondent 20).

It was encouraging to note that students were able to identify several skills that were developed through completing the assignments. They identified interpersonal skills that included good communication both by expressing themselves clearly as well as by listening to someone else's point of view. The art of negotiating and the "ability to compromise and work and accommodate people with a different style and perspective to mine" are valuable skills to have for the diverse work environment that these students will be exposed to one day (Respondent 35). They also mentioned that time management and a work ethic is necessary to not let the team down:

I was a little lazy at doing work but when you don't work alone, you than have to pressure to perform because you are not the only one (Respondent 34).

For students to answer the question posed by the case study they had to gain the necessary knowledge in some way. It was therefore encouraging to note that several respondents added the ability to research and assess different alternatives as a skill that was developed. Quite a few of the groups presented their final deliverable in a video or presentation format and this was also mentioned as a valuable skill that was developed. As one respondent commented: 
Using technology to create a video and summarizing the work in a simpler but more powerful and interesting way (Respondent 33).

All the skills mentioned by the students were comparable to those in other studies that also identified verbal communication skills, listening skills, negotiating, researching and presenting findings as skills enhanced through group work activities (Ballantine and Larres, 2007; Healy, Doran, and McCutcheon, 2018; Paguio and Jackling, 2016).

\section{Conclusion}

Cooperative learning can be seen as an effective learning approach with the average of group marks shown to be higher than individual marks earned for a case-based assignment. The results indicate that cooperative learning allowed students to exchange ideas, evaluate the input of other students and so become part of the knowledge creation process. Within the online learning environment, cooperative learning can be equally effective if time and connectivity challenges are closely monitored by the educator. Although most students indicated that they prefer to work on their own rather than in a group, they did understand the benefit of immersing themselves in a community where they can solve problems together and imitate the work environments to which they will one day be exposed.

Within group work, there might always be students that take advantage of the group effect to free ride and spend minimal effort to receive the same mark as their group members. It appears that, in this study, most group members did cooperate, gained the necessary knowledge and helped to solve the case study problem. This might be due to the higher level of maturity of the online students. The use of peer assessment might be considered to curtail uncooperative member, but is not without its challenges (Opdecam and Evereart, 2018).

In this study, although adequate guidance was given to students on how to manage and work within their groups, they were able to navigate the online environment with minimal input from the educator and found ways to connect, meet and share their ideas. Social media platforms and online meeting software played a significant role in achieving their connectedness. Group formation in this study was through randomly selected groups and although it will always be a matter of debate, it should fit in with the objectives of the cooperative learning assignment and the current status of the students (van der Laan Smith and Spindle, 2007). More intentional group formation or self-selected groups might be considered, but randomly selected groups present students with "social, communication and organizational challenges" to overcome that might be more beneficial to them in their future careers (Hilton and Phillips, 2010, p. 31).

It was encouraging to note that respondents were able to identify a number of skills that were developed through the case study approach and group assignment. Skills such as communicating well, listening with intent, negotiating a point of view, researching alternatives and solving a problem were all enhanced through their participation in their groups. Some students were also able to develop technological skills by meeting online and presenting their final work using video software. All these skills will be necessary for a successful career as a professional accountant.

This study was based on a modest sample of students within one online module. As the author is a proponent of cooperative learning, this might have affected the qualitative analysis performed. The mixed-methods approach may, however, provide a more balanced picture of the students' perceptions. As online learning has grown during the COVID-19 pandemic and forced many institutions to offer it as the only alternative, cooperative learning opportunities can be included in other programmes and modules. In order for cooperative learning to be effective in the online learning environment, educators will do well to follow a structured approach to achieve maximum benefit. Choices regarding group size, group formation and group management play an important part in the success of the group work. So too the ability of students to interact with each other virtually in synchronous as well as asynchronous formats. The set-up and management of the approach will require forethought by the educator but can lead to a rich and student-centered environment.

\section{References}

Ballantine, J. and Larres, P.M., 2007. Cooperative learning: A pedagogy to improve students' generic skills? Education and Training, 49(2), 126-137. https://doi.org.10.1108/00400910710739487.

Barnard, L., Lan, W.Y., To, Y.M., Paton, V.O. and Lai, S., 2009. Measuring self-regulation in online and blended learning environments. Internet and Higher Education 12, pp. 1-6. https://doi.org/10.1016.j.iheduc.2008.10.005. 
Bay, D. and Pacharn, P., 2017. Impact of group exams in a graduate intermediate accounting class. Accounting Education, 26(4), pp. 316-334. https://doi.org.10.1080/09639284.2017.1292465.

Borthick, A.F. and Jones, D.R., 2000. The motivation for collaborative discovery learning online and its application in an information systems assurance course. Issues in Accounting Education, 15(2), pp. 181-201.

Chan, C.K.K. and Chan, Y., 2011. Students' view of collaboration and online participation in knowledge forum. Computers \& Education, 57, pp. 1445-1457. https://doi.org/10.1016.j.comedu.2010.09.003.

Christensen, J., Harrison, J.L., Hollindale, J. and Wood, K., 2019. Implementing team-based learning (TBL) in accounting courses. Accounting Education, 28(2), pp. 195-219. https://doi.org/10.1080/09639284.2018.1535986.

Clinton, B.D. and Kohlmeyer III, J.M., 2005. The effects of group quizzes on performance and motivation to learn: Two experiments in cooperative learning. Journal of Accounting Education, 23, pp. 96-116. https://doi.org/10.1016/j/jaccedu.2005.06.001.

Delucchi, M., 2007. Assessing the impact of group projects on examination performance in social statistics. Teaching in Higher Education, 12(4), pp. 447-460. https://doi.org/10.1080/13562510701415383.

Dyball, M.C., Reid, A., Ross, P. and Schoch, H., 2007. Evaluating assessed group-work in a second-year management accounting subject. Accounting Education, 16(2), 145-162. https://doi.org/10.1080/09639280701234385.

Garrison, D.R., Anderson, T. and Archer, W., 2000. Critical inquiry in a text-based environment: Computer conferencing in higher education. The Internet and Higher Education, 2(2-3), pp. 87-105.

Gikandi, J.W., Morrow, D. and Davis, N.E., 2011. Online formative assessment in higher education: A review of the literature. Computers \& Education, 57, 2333-2351. https://doi.org/10.10.1016/j.compedu.2011.06.004.

Gillies, R., 2014. Cooperative learning: Developments in research. International Journal of Educational Psychology, 3(2), pp. 125-140. https://doi.org/10.4471/ijep.2014.08.

Given, L.M. (ed.), 2008. The Sage Encyclopaedia of Qualitative Research Methods, 2, 697-698. Thousand Oaks, CA: Sage Publishing.

Globenewswire, 2021. Global e-learning market size \& trends will reach USD 374.3 billion by 2026: Facts \& factors. Available at <https://www.globenewswire.com/news-release/2020/12/17/2146962/0/en/Global-E-learning-MarketSize-Trends-Will-Reach-USD-374-3-Billion-by-2026-Facts Factors.html\#: :text=According\%20to\%20the\%20research\%20study,14.6\%25\%20from\%202019\%20to\%202026> [Accessed 8 March 2021].

Graham, C.R. and Misanchuk, M., 2004. Computer-mediated learning groups: Benefits and challenges to using groupwork in online learning environment. In Online collaborative learning: Theory and practice, edited by T.S. Roberts, Hershey PA: Idea Group Publishing.

Hämäläinen, R. and Vähäsantanen, K., 2011. Theoretical and pedagogical perspectives on orchestrating creativity and collaborative learning. Educational Research Review, 6, pp. 169-184. https://doi.org/10.1016/i.edurev.2011.08.001.

Haythornthwaite, C., 2006. Facilitating collaboration in online learning. Journal of Asynchronous Learning Networks, 10(1), pp. 7-24.

Healy, M., Doran, J. and McCutcheon, M., 2018. Cooperative learning outcomes from cumulative experiences of group work: differences in student perceptions. Accounting Education, 27(3), pp. 286-308. https://doi.org/10.1080/09639284.2018.1476893.

Henning, E., van Rensburg, W. and Smit, B., 2004. Finding your way in qualitative research. Pretoria: Van Schaik Publishers.

Hernández-Selles, N., Munoz-Carril, P. and González-Sanmamed, M., 2019. Computer-supported collaborative learning: An analysis of the relationship between interaction, emotional support and online collaborative tools. Computers \& Education, 138, pp. 1-12. https://doi.org/10.1016/j.compedu.2019.04.012.

Hilton, S. and Phillips, F., 2010. Instructor-assigned and student-selected groups: A view from inside. Issues in Accounting Education, 25(1), pp. 15-33. https://doi.org/10.10.2308/iace.2010.25.1.15.

Hiltz, S.R., Coppola, N., Rotter, N., Turoff, M. and Benbunan-Fich, R., 2011. Measuring the importance of collaborative learning for the effectiveness of ALN: A multi-measure, multi-method approach. Journal of Asynchronous Learning Networks, 4(2), pp. 103-125.

Holzweiss, P.C., Joyner, S.A., Fuller, M.B., Henderson, S. and Young, B., 2014. Online graduate students' perceptions of best learning experiences. Distance Education, 35(3), pp. 311-323. https://doi.org/10.1080/01587919.2015.955262.

Johnson, D.W. and Johnson, R.T., 1996. Cooperation and the use of technology. In Handbook of research for educational communications and technology, edited by D.H. Jonassen. New York: Simon and Schuster: Macmillan.

Johnson, D.W. and Johnson, R.T., 2009. An educational psychology success story: Social interdependence theory and cooperative learning. Educational Researcher, 38(5), pp. 365-379. https://doi.org/10.3102/0013189x09339057.

Jopp, R. and Cohen, J., 2020. Choose your own assessment - assessment choice for students in online higher education. Teaching in Higher Education, doi:10.1080/13562517.2020.1742680.

Khosa, D.K. and Volet, S.E., 2013. Promoting effective collaborative case-based learning at university: A metacognitive intervention. Studies in Higher Education, 38(6), pp. 870-889. https://doi.org/10.1080/03075079.2011.604409.

Kumi-Yeboah, A., Yuan, G. and Dogbey, J., 2017. Online collaborative learning activities: The perceptions of culturally diverse graduate students. Online Learning, 21(4), pp. 5-28. https://doi.org/10.24059/olj.v21i4.1277.

Malan, M. and van Dyk, V., 2020. Students' experience of pervasive skills acquired through sponsored projects in an undergraduate accounting degree. South African Journal of Accounting Research. https://doi.org/10.1080/10291954.2020.1827851. 
McInnerney, J.M. and Roberts, T.S., 2004. Collaborative or Cooperative Learning? In Online collaborative learning: Theory and practice, edited by T.S. Robert., Hershey PA: Idea Group Publishing.

Mystakidis, S., Berki, E. and Valtanen, J., 2019. The Patras blended strategy model for deep and meaningful learning in quality life-long distance education, The Electronic Journal of e-Learning, 17(2), pp. 66-78, available online at www.ejel.org.

Nkhoma, M.Z., Lam, T.K., Sriratanaviriyakul, N., Richardson, J. Kam, B. and Lau, K.H., 2017. Unpacking the revised Bloom's taxonomy: developing case-based learning activities. Education + Training, 59(3), pp.250-264. https://doi.org/10.1108/ET-03-2016-0061.

Oosthuizen, H., De Lange, P., Wilmshurst, T. and Beatson, N., 2020. Teamwork in the accounting curriculum: Stakeholder expectations, accounting students' value proposition, and instructors' guidance. Accounting Education, https://doi.org.10.1080/09639284.2020.1858321.

Opdecam, E. and Everaert, P., 2012. Improving student satisfaction in a first-year undergraduate accounting course by team learning. Issues in Accounting Education, 27(1), pp. 53-82. https://doi.org/10.2308/iace-10217.

Opdecam, E. and Everaert, P., 2018. Seven disagreements about cooperative learning. Accounting Education, 27(3), pp. 223-233. https://doi.org.10.1080/09639284.2018.1477056.

Opdecam, E., Everaert, P., Van Keer, H. and Buysschaert, F., 2014. Preferences for team learning and lecture-based learning among first-year undergraduate accounting students. Research in Higher Education, 55(4), pp. 400-432. https://doi.org.10.1007/s11162-013-9315-6.

Paguio, R. and Jackling, B., 2016. Teamwork from accounting graduates: What do employers expect? Accounting Research Journal, 29(3), pp. 348-366. https://doi.org/10.1108/ARJ-05-2014-0049.

Piaget, J., 1971. The psychology of intelligence: Sixth impression. London: Routledge \& Kegan Paul.

Pittaway, S.M. and Moss, T., 2014. "Initially we were just names on a computer screen": Designing engagement in online teacher education. Australian Journal of Teacher Education, 39(7), pp. 140-156. http://dx.doi.org/10.14221/ajte.2014v39n7.10.

Raza, S.A., Qazi, W. and Umer, B., 2020. Examining the impact of case-based learning on student engagement, learning motivation and learning performance among university students. Journal of Applied Research in Higher Education, 12(3), pp. 517-533. https://doi.org/10.1108/JARHE-05-2019-0105.

Redmond, P., Heffernan, A., Abawi, L., Brown, A. and Henderson, R., 2018. An online engagement framework for higher education. Online Learning, 22(1), pp. 183-204. https://doi.org/10.24059/olj.v22i1.1175.

Robinson, H.A., Kilgore, W. and Warren, S.J., 2017. Care, communication, learning support: Designing meaningful online collaborative learning. Online Learning Journal, 21(4), pp. 29-51. https://doi.org/10/24059/olj.v21i4.1240.

Samkin, G. and Keevy, M., 2019. Using a stakeholder developed case study to develop soft skill. Meditari Accountancy Research, 27(6), pp. 862-882. https://doi.org/10.1108/MEDAR-01-2018-0260.

Sangster, A., Stoner, G. and Flood, B., 2020. Insights into accounting education in a COVID-19 world. Accounting Education, 29(5), pp. 431-562. https://doi.org/10/1080/09639284.2020.1808487.

Shawver, T.J., 2020. An experimental study of cooperative learning in advanced financial accounting courses. Accounting Education, 29(3), pp. 247-262. https://doi.org/10.1080/09639284.2020.1736589.

Swan, K., Shen, J. and Hiltz, S.R., 2006. Assessment and collaboration in online learning. Journal of Asynchronous Learning Networks, 10(1), pp. 45-62.

Tan, H.C., 2019. Using a structured collaborative learning approach in a case-based management accounting course. Journal of Accounting Education, 49. https://doi.org/10.1016/j.jaccedu.2019.100638.

Tashakkori, A. and Creswell, J.W., 2007. The new era of mixed methods. Journal of Mixed Methods Research, 1(1), pp. 3-7.

UNESCO, 2021. Education: From disruption to recovery. UNESCO. Available at <https://en.unesco.org/covid19/educationresponse> [Accessed 8 March 2021].

van der Laan Smith, J. and Spindle, R.M., 2007. The impact of group formation in a cooperative learning environment. Journal of Accounting Education, 25, pp. 153-167. https://doi.org/10.1016/j.jaccedu.2007.09.002.

Venter, A., 2019. Social media and social capital in online learning. South African Journal of Higher Education, 33(3), pp. 241-257.

Vygotsky, L.S., 1978. Mind in society: The development of higher psychological processes. Cambridge, MA: Harvard University Press.

Wolverton, C.C., Guidry Hollier, B.N. and Lanier, P.A., 2020. The impact of computer self-efficacy on student engagement and group satisfaction in online business courses. The Electronic Journal of e-Learning, 18(2), pp. 175-188, available online at www.ejel.org.

Yazici, H.J., 2004. Student perceptions of collaborative learning in operations management classes. Journal of Education for Business, 80(2), pp. 110-118. https://doi.org/10.3200/JOEB.80.2.110-118. 